\title{
18
}

\section{Mechanisms and Drivers of Soil Salinity in Coastal Bangladesh}

\author{
Mashfiqus Salehin, Md. Mahabub Arefin Chowdhury, \\ Derek Clarke, Shahjahan Mondal, Sara Nowreen, \\ Mohammad Jahiruddin, and Asadul Haque
}

\subsection{Introduction}

The coastal area of Bangladesh covers about one-fifth of the country and represents more than 30 percent of the country's cultivable lands (Rasel et al. 2013). Livelihoods in this region are thus largely dependent on agricultural practices; however, dry season agricultural productivity in this region is low compared to the national average (see Chap. 24), which is considered to be one of the major reasons for high incidence of poverty (Lázár et al. 2015). Soil salinity is the dominant factor behind the low

\footnotetext{
The original version of this chapter was revised. The second author's name was incorrect. The chapter has been updated with the correct name and affiliation of the author. An erratum to this chapter can be found at https://doi.org/10.1007/978-3-319-71093-8_30
}

M. Salehin $(\varangle) \bullet$ Md. Mahabub Arefin Chowdhury $\bullet$ S. Mondal $\bullet$ S. Nowreen Institute of Water and Flood Management, Bangladesh University of Engineering and Technology, Dhaka, Bangladesh

D. Clarke

Faculty of Engineering and the Environment and Tyndall Centre for Climate Change Research, University of Southampton, Southampton, UK 
crop productivity, which is further compounded by inappropriate and/or faulty water control structures in some areas.

A total of 1.05 million hectares of land out of 2.88 million hectares in the Khulna and Barisal divisions are affected by different degrees of soil salinity within the coastal and offshore lands (SRDI 2010) (Fig. 18.1). The spatial pattern of soil salinity is similar to that of river water salinity (Fig. 18.2) and groundwater salinity (Fig. 18.3). Large areas of land remain fallow in the dry season (January-May) because of soil salinity, lack of good quality irrigation water, and problems with water control (mostly drainage) (Mondal et al. 2006; SRDI 2010).

The coverage of dry season irrigated Boro crop within the study area (29.3 percent) is much lower than the national average of around 63
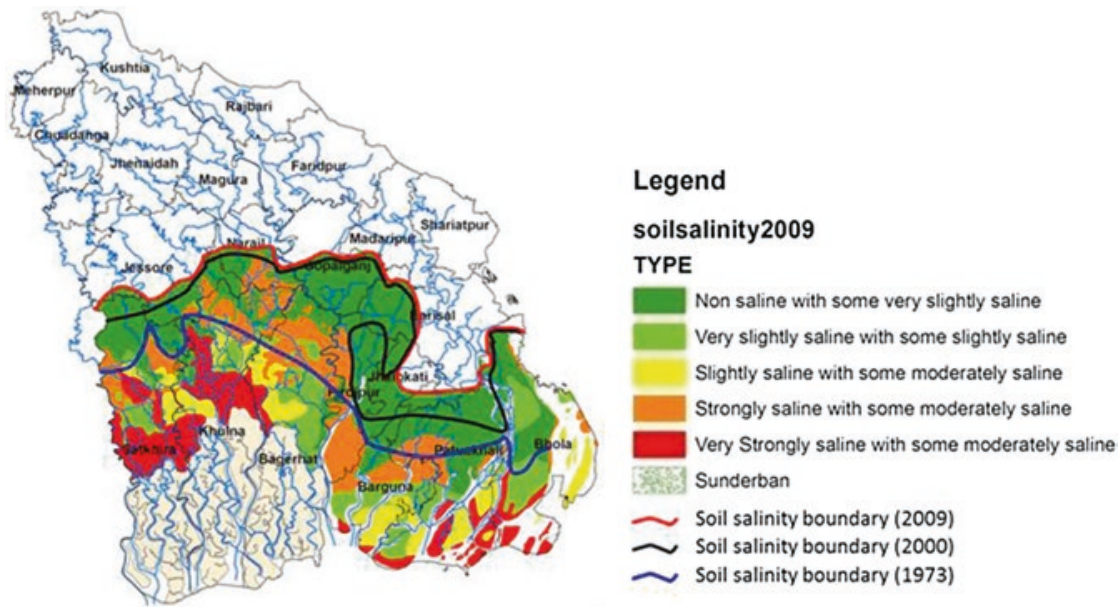

Fig. 18.1 Soil salinity in the south-west coastal region in 2009. Figure shows different degrees of salinity in different places and the increase in soil salinity from 1973 to 2009 (Based on data from the Bangladesh Soil Resources Development Institute)

M. Jahiruddin

Department of Soil Science, Bangladesh Agricultural University, Mymensingh, Bangladesh

A. Haque

Department of Soil Science, Patuakhali Science and Technology University, Patuakhali, Bangladesh 


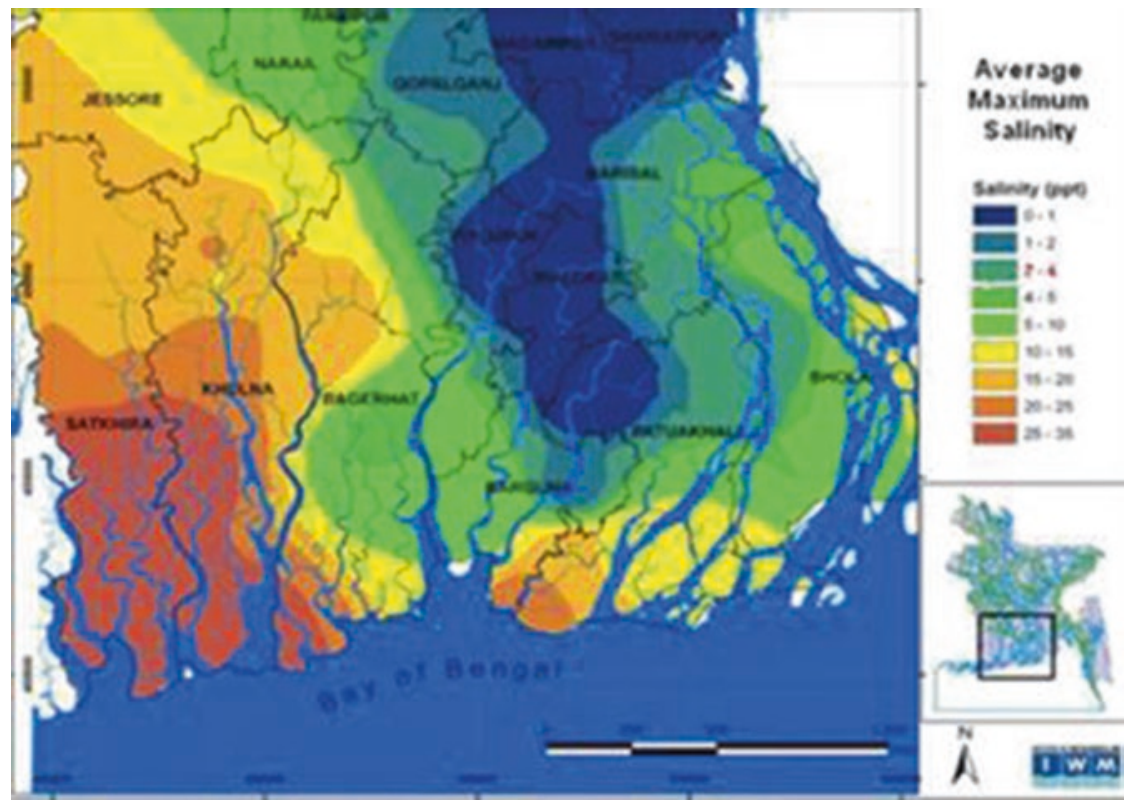

Fig. 18.2 Maximum average river salinity (ppt) in the south-west coastal region (Based on data from the Bangladesh Water Development Board)

percent. With poor dry season surface water resources, groundwater is the primary source of irrigation water in many areas. However, shallow aquifers in most of the south-west coastal region are affected by different levels of salinity due to seawater intrusion and interaction with saline surface water (Fig. 18.3). This has resulted in the extraction of groundwater from deeper aquifers using tube wells.

\subsection{Factors Influencing Soil Salinity in Coastal Bangladesh}

There has been a progressive increase in soil salinity in terms of intensity, and affected area over the last four decades with saline areas increasing from 0.83 million hectares in 1973 to about 1.05 million hectares in 2009 (SRDI 2010). There was an increase in affected area by 0.19 million 


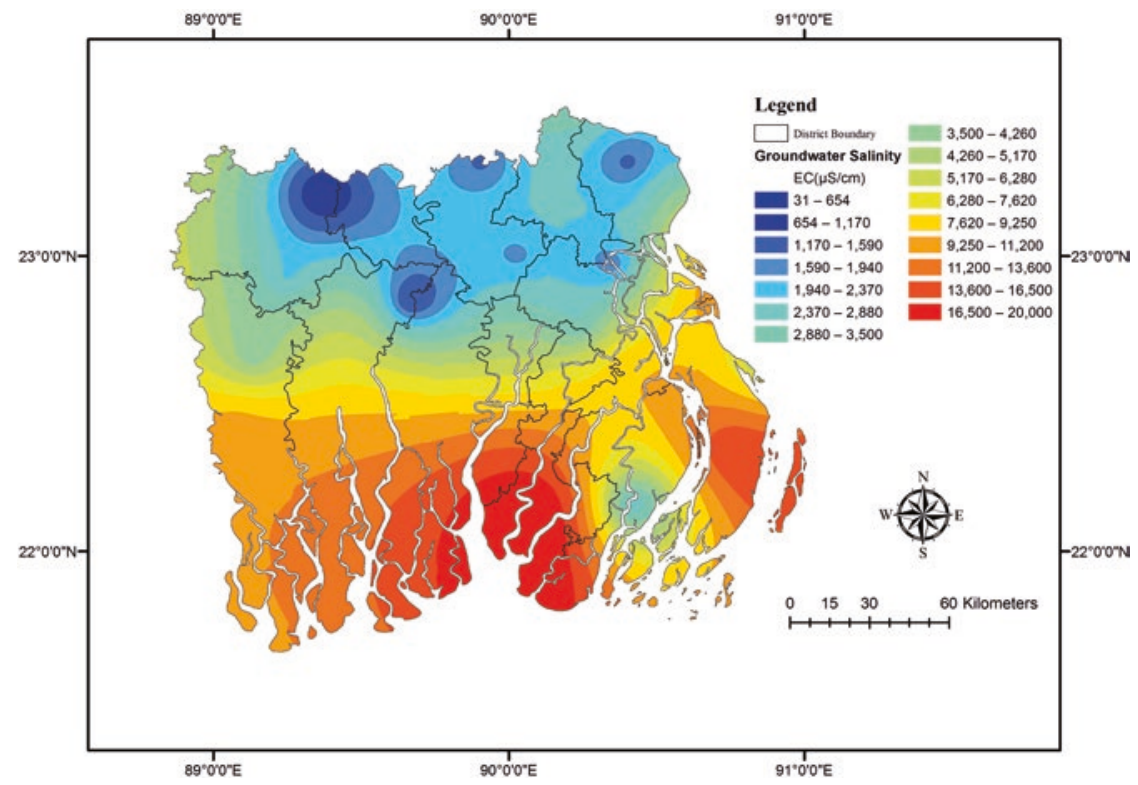

Fig. 18.3 Shallow groundwater salinity in the study area (Based on data from the Bangladesh Water Development Board)

hectares from 1973 to 2000 and a further increase by 0.04 million hectares from 2000 to 2009 (SRDI 2010).

There are numerous interacting drivers that influence soil salinity in Bangladesh (Table 18.1) including irregular rainfall, evaporation, saline river water inundation in both unprotected and protected areas (polders), depth to and salinity of groundwater, irrigation using saline water, storm surge inundation, and brackish shrimp farming (SRDI 2010; Rashid and Islam 2007; Haque et al. 2008; Rasel et al. 2013). As these factors vary spatially in the south-west coastal region, their relative effects on soil salinity are also spatially variable and complex.

Seasonal variation in soil salinity is quite distinct; top soil salinity gradually increases from January, reaches a maximum usually in April or May, and then starts to gradually decrease with the onset of monsoon and reaches the seasonal low usually in September or October when salts are sufficiently flushed out by monsoon rainfall. However, at some places greater accumulation of salts occurs due to a combination of the factors listed in Table 18.1. 
Table 18.1 Salinity mechanisms and processes in coastal Bangladesh

\begin{tabular}{|c|c|c|}
\hline $\begin{array}{l}\text { Mechanism/ } \\
\text { drivers }\end{array}$ & Processes & $\begin{array}{l}\text { Long-term change } \\
\text { factors }\end{array}$ \\
\hline $\begin{array}{l}\text { Climate } \\
\text { variability }\end{array}$ & $\begin{array}{l}\text { Irregular rainfall (less rainfall not } \\
\text { being able to flush out salts in } \\
\text { monsoon; less rainfall forcing more } \\
\text { irrigation in dry season) }\end{array}$ & Increased irrigation \\
\hline $\begin{array}{l}\text { Groundwater } \\
\text { salinity }\end{array}$ & $\begin{array}{l}\text { Accumulation of salts from capillary } \\
\text { rise of saline groundwater table }\end{array}$ & $\begin{array}{l}\text { Increased sea levels } \\
\text { Increased river } \\
\text { salinity } \\
\text { Increased pumping in } \\
\text { upstream } \\
\text { freshwater zones }\end{array}$ \\
\hline $\begin{array}{l}\text { Depth to water } \\
\text { table }\end{array}$ & $\begin{array}{l}\text { Capillary rise (water table is }<2 \mathrm{~m} \\
\text { from surface) }\end{array}$ & $\begin{array}{l}\text { Increased pumping } \\
\text { Sea-level rise }\end{array}$ \\
\hline $\begin{array}{l}\text { Cyclonic storm } \\
\text { surges }\end{array}$ & $\begin{array}{l}\text { Overtopping of polders } \\
\text { Trapped saline water in low-lying } \\
\text { floodplain areas with silted up } \\
\text { drainage canals } \\
\text { Persistent inundation of tidal plains } \\
\text { through embankment breaches }\end{array}$ & $\begin{array}{l}\text { Higher sea levels } \\
\text { Increased frequency } \\
\text { of surges }\end{array}$ \\
\hline $\begin{array}{l}\text { River water } \\
\text { salinity }\end{array}$ & $\begin{array}{l}\text { Direct tidal inundation in unprotected } \\
\text { areas } \\
\text { Tidal inundation in polders through } \\
\text { embankment breach and/or due to } \\
\text { faulty water control structures and } \\
\text { poor management } \\
\text { Lateral seepage of saline river water } \\
\text { through soil/embankment }\end{array}$ & $\begin{array}{l}\text { Reduced river flows } \\
\text { due to climate } \\
\text { variability } \\
\text { Reduced river flows } \\
\text { due to upstream } \\
\text { diversion } \\
\text { Reduced river flows } \\
\text { due to upstream } \\
\text { dams } \\
\text { Sea-level rise }\end{array}$ \\
\hline $\begin{array}{l}\text { Salinity of } \\
\text { irrigation } \\
\text { water }\end{array}$ & $\begin{array}{l}\text { Irrigation with saline river or } \\
\text { groundwater }\end{array}$ & $\begin{array}{l}\text { Increased irrigation } \\
\text { for leaching } \\
\text { Saline intrusion into } \\
\text { groundwater } \\
\text { aquifers }\end{array}$ \\
\hline $\begin{array}{l}\text { Brackish shrimp } \\
\text { cultivation }\end{array}$ & $\begin{array}{l}\text { Deliberate introduction of saline } \\
\text { water inside polders } \\
\text { Lateral seepage from shrimp ghers to } \\
\text { adjacent land } \\
\text { Contamination of shallow } \\
\text { groundwater }\end{array}$ & $\begin{array}{l}\text { National policies } \\
\text { Market forces/prices } \\
\text { Power relations }\end{array}$ \\
\hline
\end{tabular}

Modified from Salehin et al. (2014) and Clarke et al. (2015) 


\subsubsection{Groundwater Salinity and Depth to Groundwater Table}

Capillary rise causes salt accumulation from shallow groundwater which commonly occurs in irrigated areas in the dry Rabi season (Brammer 2014). Once the water table reaches a critical depth below the ground surface, evaporation of this water can occur via capillary rise, transporting soluble salts with it to the active root zone and top soil surface (Beltrán 1999; Ayers and Westcot 1994; Gupta and Khosla 1996). The critical depth may vary from $1 \mathrm{~m}$ in coarse textured soil to a few meters in fine textured soils (Gupta and Khosla 1996).

Two important considerations thus are the following: at what depth is the groundwater and how saline is the groundwater? Depth of groundwater can be influenced by increased sea level in the future thus contributing to increased salt accumulation in the soil. Groundwater salinity is anticipated to be negatively impacted by lateral seawater intrusion due to accelerated sea-level rise, increased river salinity resulting from reduction of river flows and sea-level rise, and prolonged inundation induced by cyclonic storm surges. Figure 18.4 shows that in dry season (JanuaryMay), the depth to groundwater is within 0-1.5 $\mathrm{m}$ in many places in the eastern part of the region. In the monsoon season (July-November), the water table becomes shallow in most regions, but the key difference is that the shallow groundwater is primarily fresh rainwater.

Murshid (2012) indicated that groundwater pumping from shallow wells less than $200 \mathrm{~m}$ from a polder boundary can induce an inflow of brackish water under the polder and into the irrigation well. Additionally, groundwater salinity is anticipated to be negatively impacted by rising sea level and subsidence which would push the seawater interface further inland. This would be exacerbated by an increase in river salinity due to reduction in river flows.

\subsubsection{River Water Salinity}

There are major river channels along with numerous small rivers and estuarine/tidal creeks that carry saline water from the sea to interior lands in the dry season due to tidal exchange (see Chap. 17). The coastal land 

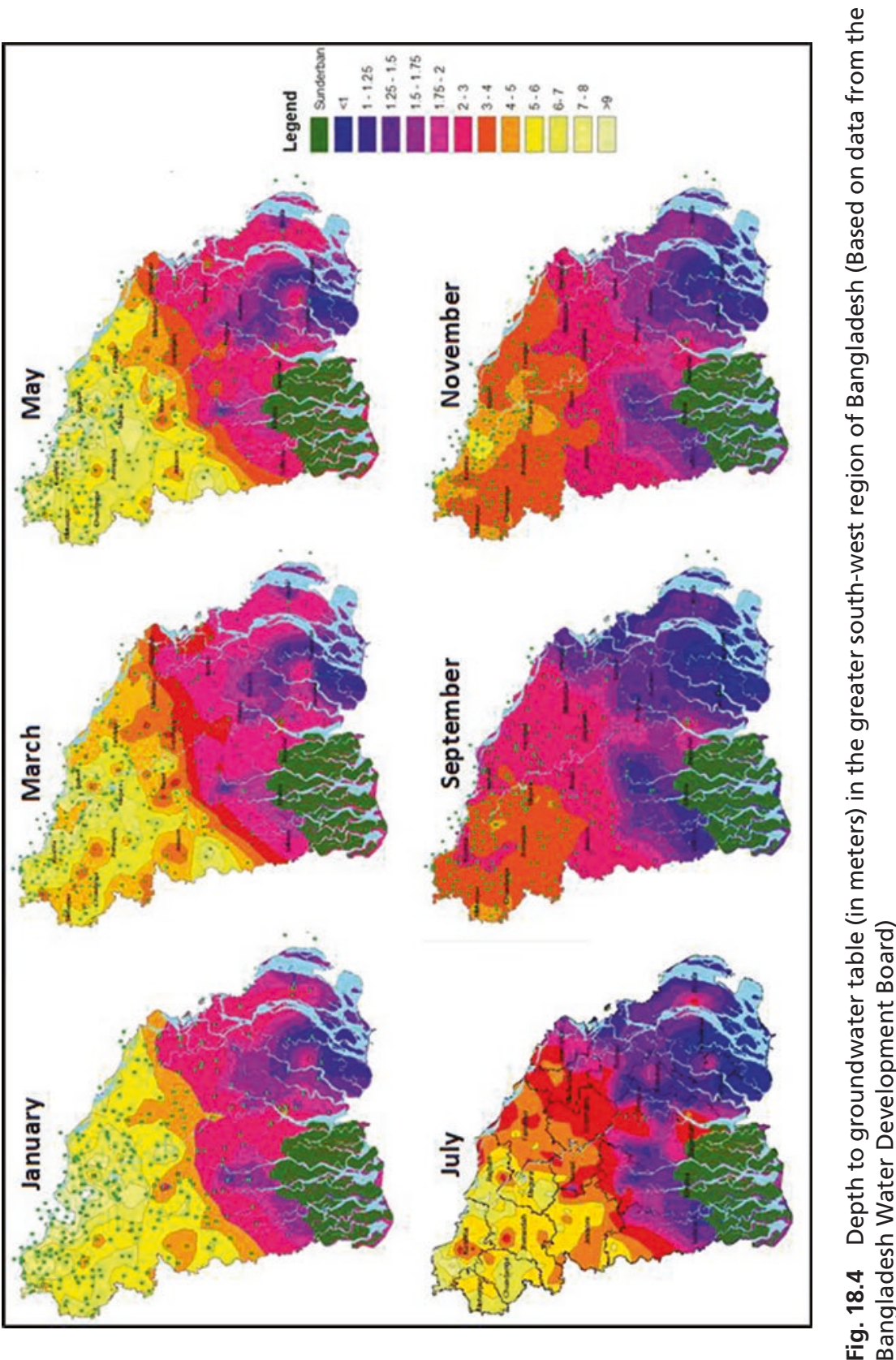
elevation is typically between 0.9 and $2.1 \mathrm{~m}$ above mean sea level (Iftekhar and Islam 2004; Haque 2006). Tide or surges can rise up to $1.3 \mathrm{~m}$ above the general ground level in the dry season and can inundate wide areas (Rasel et al. 2013). Tides and surges of brackish sea water (19-28 parts per thousand (ppt)) can propagate up to $200 \mathrm{~km}$ inland in times of reduced river discharge (Mondal et al. 2006; Dasgupta et al. 2014). Inundation can also take place inside the polders through embankment breaches or due to poor management of the outlet gates and via seepage through soils or embankments.

This mechanism is exacerbated by reduced dry reason river flows. Fresh water diversions from the river Ganges has meant river flows into the western part of the south-west coastal zone is substantially reduced in the dry season. This results in high river water salinity in and around Satkhira, Khulna, and Bagerhat districts. In contrast, in the eastern area, fresh water delivery by the Padma and Lower Meghna rivers means that salinity is concentrated nearer the coast (Fig. 18.2).

There is a strong association between river water salinity and soil salinity in the eastern part (Satkhira, Khulna, and Bagerhat districts) and southernmost regions of Barguna, Patuakhali, and Bhola districts (Fig. 18.5). However, a more detailed analysis shows that the association is weaker further inland from the sea where river salinity is lower, yet soil salinity remains high. This implies that factors other than river salinity also play important roles in determining soil salinity. A multiple regression analysis shows that soil salinity can be strongly related to depth to the groundwater table and rainfall in the dry season as well as river water salinity.

The fact that river water salinity plays a dominant role in controlling soil salinity has significant implications. A probable future scenario for this region comprises reduced dry season river flows (caused by climatic change and increased damming and diversion upstream) and accelerated relative sea-level rise (caused by global sea-level rise, subsidence and reduced sediment delivery due to river damming), and the soil salinity problem is expected to further intensify and extend over wider areas (see Chap. 17). 


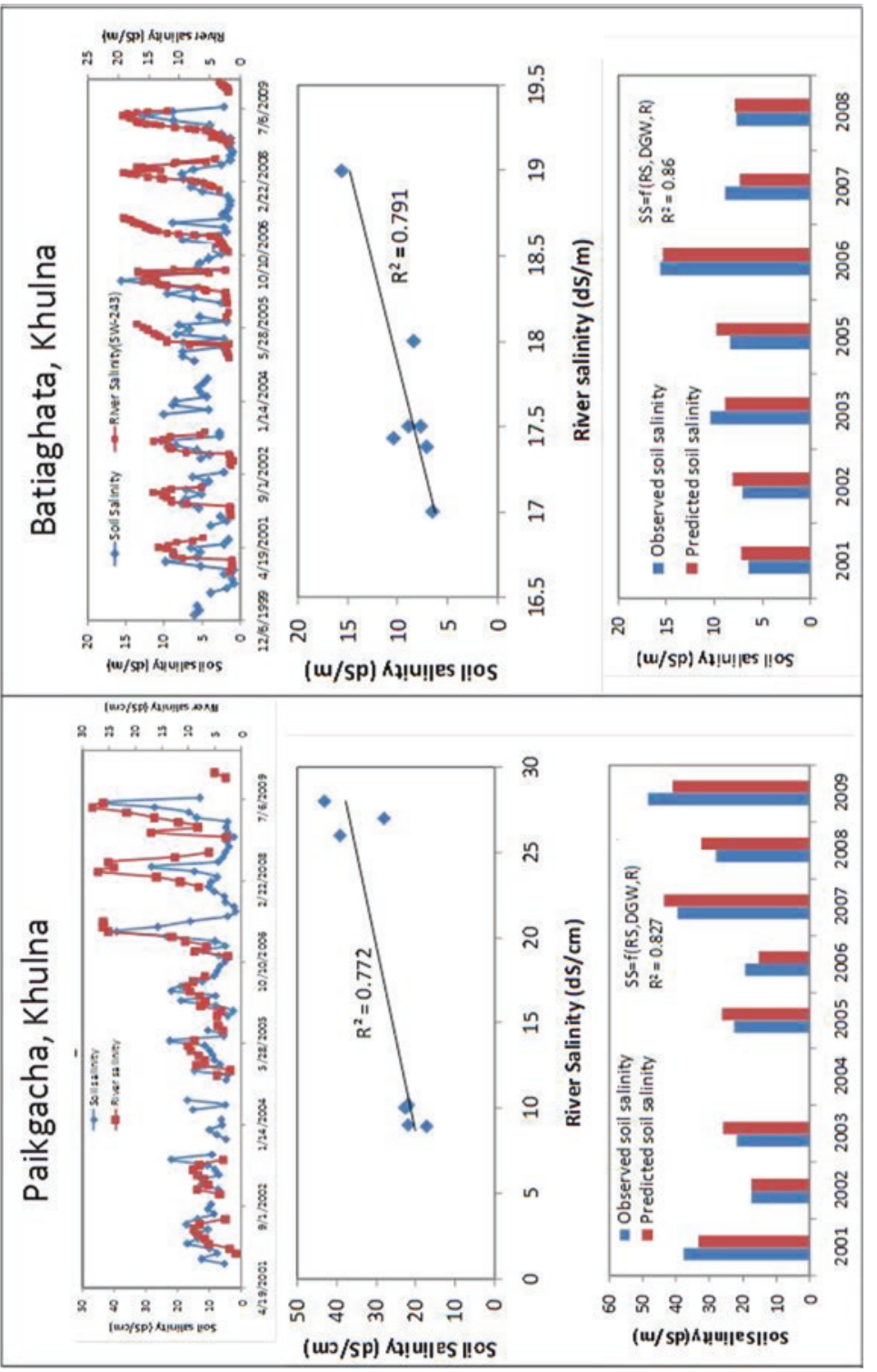

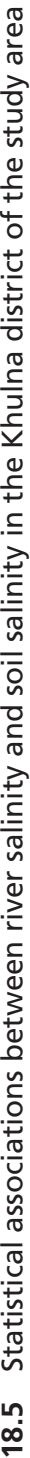

ㅎํ 


\subsubsection{Cyclonic Storm Surges}

Cyclonic storm surges have been another cause of increase in soil salinity in the surge affected areas in Bangladesh (see Chap. 8). The impacts are frequently prolonged for several years. For example, Cyclone Aila (2007) inundated large areas in Dacope Upazila of Khulna district via overtopping of polders and breaches in the embankments. As rehabilitation of the polder dykes was slow, the tidal floodplain areas were repeatedly inundated by saline tidal water for one to two years, with saline water trapped in low-lying areas with silted up drainage canals. It took two to three monsoons to flush out the accumulated salts before agriculture could be partially restored, which caused prolonged suffering to the local people whose livelihoods are intertwined with agriculture (Kabir et al. 2015).

\subsubsection{Irrigation Water Quality and Monsoon Rainfall}

Clarke et al. (2015) showed that accumulation of salts on the agricultural land in the dry season is controlled by the amount and quality of irrigation water applied. An increase in the salinity of sources of dry season irrigation water will lead to increased salt accumulation in soils. Other key factors were the effectiveness of the monsoon rainfall in removing water by leaching/disposal through effective and well-maintained drainage systems. Their analysis showed that irrigating with water at up to four parts per thousand (ppt) can be sustainable, but if the dry season irrigation water quality goes above $5 \mathrm{ppt}$, the monsoon rainfall is unable to flush out the salt deposits. It was found that agricultural productivity in the Barisal, Patuakhali, and Bhola districts is likely to fall by 25 percent by 2050 , with some regions expected to experience dry season crop yield reductions of 50 percent. Regions which are already experiencing severe salinity in Barisal and Khulna divisions are expected to see salinities of greater than 20 ppt by the end of the century, effectively curtailing dry season agriculture (Fig. 18.6). 

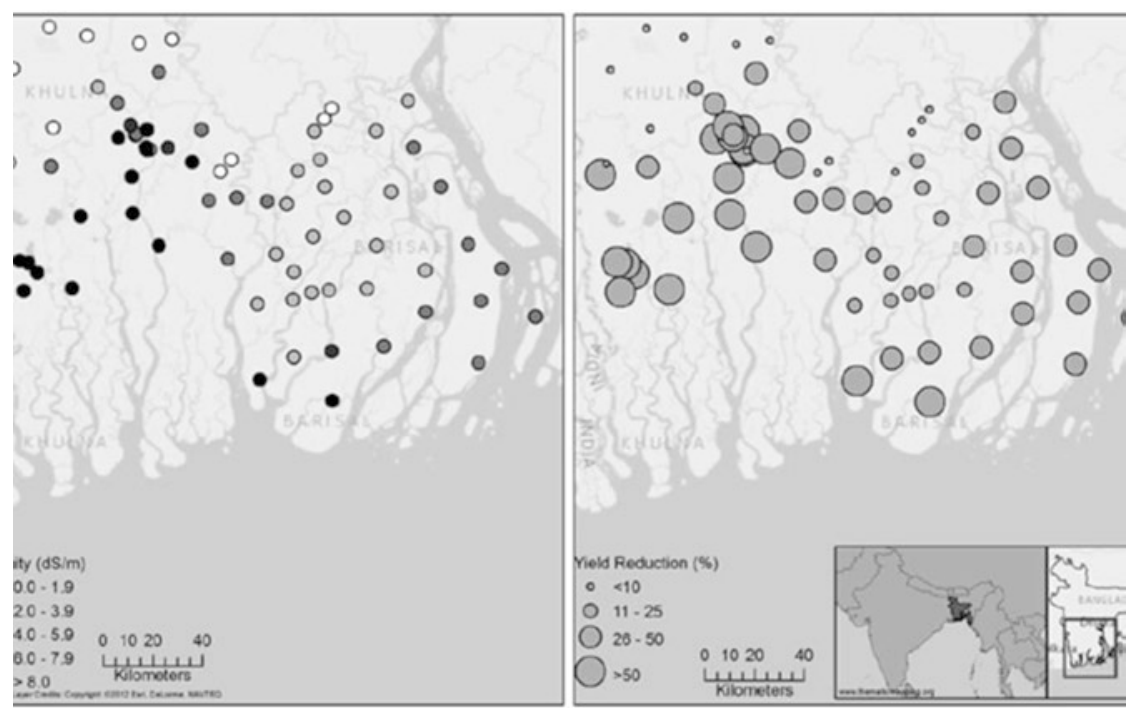

Fig. 18.6 Projections of future 2050 river water salinities (left) and simulated crop yield reduction due to increased irrigation water salinity (right) (Clarke et al. 2015-Published by The Royal Society of Chemistry)

\subsubsection{Brackish Shrimp Cultivation}

Shrimp farming is the third largest earner of foreign currency, with production primarily based in southern regions around Satkhira, Khulna, and Bagerhat (Begum and Alam 2002). Shrimp culture is one of the most attractive land use practices as the profits generated exceed those of traditional agriculture (Hossain et al. 2004). However, shrimp culture has not been free from its negative effects, especially with the brackish shrimp (locally known as Bagda) culture. There has been a rapid growth of Bagda over more than two decades in the southern part of the coastal region by taking advantage of high river water salinity (Fig. 18.7) (see Chap. 20). Extensive shrimp ponds (ghers) were constructed with saline water brought from surrounding rivers via canals. Unfortunately, this kind of shrimp culture has led to the deterioration of coastal soils and ground/surface water sources through increased salinization (Rahman et al. 2013; Kabir and Eva 2014; Karim et al. 1990). Brackish shrimp culture concentrates in the saline areas where soil salinity is principally impacted by river water salinity in the dry season. 


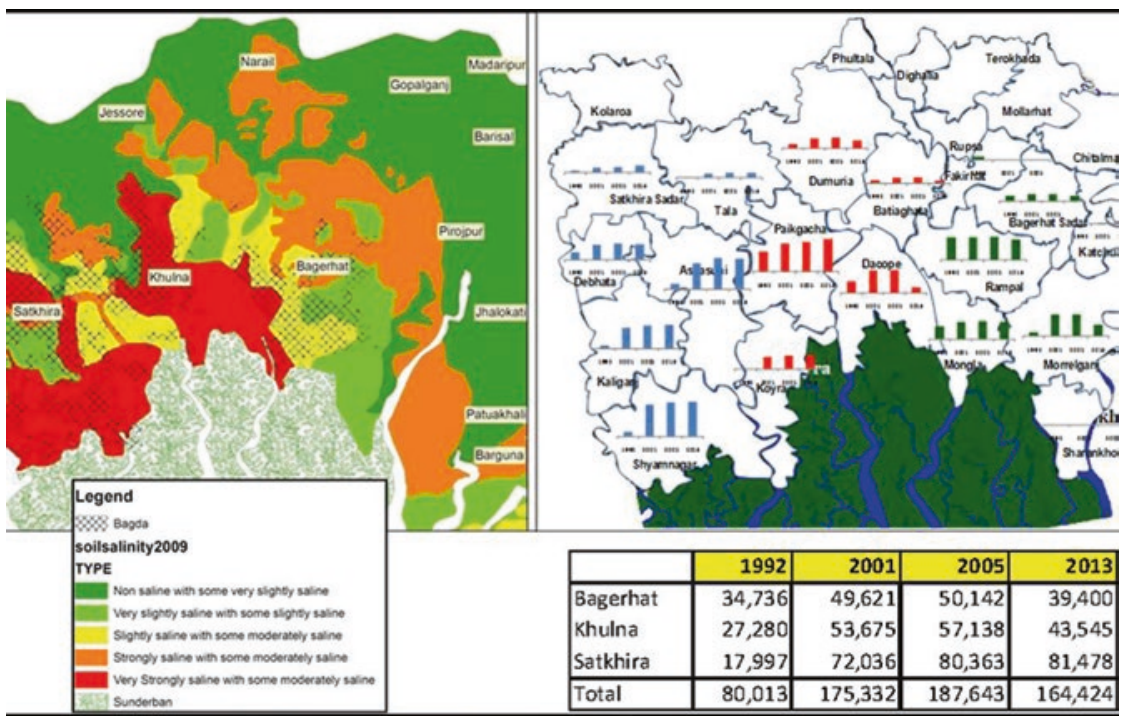

Fig. 18.7 Growth of brackish water shrimp culture in Satkhira, Khulna, and Bagerhat districts in Khulna Division. The left figure shows brackish shrimp culture concentrated in the saline areas where soil salinity is principally impacted by river water salinity. The right figure shows a continual increase in brackish shrimp culture in Satkhira district, while Khulna and Bagerhat districts show a recent decline

\subsection{Conclusions}

Soil salinity is a major constraint of agricultural production and human livelihoods in the coastal region of south-west Bangladesh, but there are multiple relationships between groundwater salinity, surface water salinity, human management (or mismanagement) of water resources, and the resulting accumulation of salts in the soils of the farmlands. When considering future trajectories of environmental change, it will be vital to assess the interactions between the drivers of soil salinity and to be aware of the interactions between surface water and groundwater. Increases in river and groundwater salinity will have significant future implications given their important roles in affecting salt accumulation in soil. River salinity may increase due to accelerated sea-level rise and reduction of dry season river flows. Groundwater is closely linked to the surface hydrology, and it cannot be assumed to be independent of external factors and 
environmental change. Aquifer water quality can be affected by lateral seawater intrusion due to accelerated sea-level rise, increased river salinity being exchanged with shallow groundwater, cyclonic storm surges, human activities such as groundwater pumping, and deliberate inundation of farmland for brackish aquaculture. Strategic water plans must take note that poor management of surface water and groundwater resource use may result in a long-term degradation of soil quality which will be difficult to reverse.

\section{References}

Ayers, R.S., and D.W. Westcot. 1994. Water quality for agriculture. FAO irrigation and drainage paper 29. Rome: Food and Agriculture Organisation (FAO). http://www.fao.org/docrep/003/T0234E/T0234E00.htm. Accessed 22 May 2017.

Begum, A., and S.M.N. Alam. 2002. Social and economic impacts of shrimp disease among small-scale, coastal farmers and communities in Bangladesh. Primary aquatic animal health care in rural, small-scale, aquaculture development. Rome: Food and Agriculture Organisation (FAO). http://www.fao.org/ docrep/005/Y3610E/y3610E18.htm. Accessed 27 Apr 2017.

Beltrán, J.M. 1999. Irrigation with saline water: Benefits and environmental impact. Agricultural Water Management 40 (2-3): 183-194. https://doi. org/10.1016/s0378-3774(98)00120-6.

Brammer, H. 2014. Bangladesh's dynamic coastal regions and sea-level rise. Climate Risk Management 1: 51-62. https://doi.org/10.1016/j.crm.2013.10.001.

Clarke, D., S. Williams, M. Jahiruddin, K. Parks, and M. Salehin. 2015. Projections of on-farm salinity in coastal Bangladesh. Environmental ScienceProcesses and Impacts 17 (6): 1127-1136. https://doi.org/10.1039/c4em00682h.

Dasgupta, S., F.A. Kamal, Z.H. Khan, S. Choudhury, and A. Nishat. 2014. River salinity and climate change: Evidence from coastal Bangladesh. Policy working paper series 6817. Washington, DC: The World Bank. http://documents. worldbank.org/curated/en/522091468209055387/River-salinity-andclimate-change-evidence-from-coastal-Bangladesh. Accessed 11 Apr 2014.

Gupta, S.K., and B.K. Khosla. 1996. Salinity control in the root zone of irrigated agriculture. Proceedings of the workshop on water logging and soil salinity in irrigated agriculture, March 12-15, New Delhi. 
Haque, S.A. 2006. Salinity problems and crop production in coastal regions of Bangladesh. Pakistan Journal of Botany 38 (5): 1359-1365.

Haque, M.A., D.E. Jharna, M.N. Uddin, and M.A. Saleque. 2008. Soil solution electrical conductivity and basic cations composition in the rhizosphere of lowland rice in coastal soils. Bangladesh Journal of Agricultural Research 33 (2): 243-250.

Hossain, S., S.M.N. Alam, C.K. Lin, H. Demaine, Y. Sharif, A. Khan, N.G. Das, and M.A. Rouf. 2004. Integrated management approach for shrimp culture development in the coastal environment of Bangladesh. World Aquaculture, World Aquaculture Society, Louisiana State University, Baton Rouge. 35-44. https://www.was.org/Magazine/Contents.aspx?Id=8. Accessed 22 May 2017. Iftekhar, M.S., and M.R. Islam. 2004. Managing mangroves in Bangladesh: A strategy analysis. Journal of Coastal Conservation 10: 139. https://doi. org/10.1652/1400-0350(2004)010[0139:MMIBAS]2.0.CO;2.

Kabir, H., and I.J. Eva. 2014. Environmental impacts on shrimp aquaculture: The case of Chandipur village at Debhata upazilla of Satkhira district, Bangladesh. Journal of the Asiatic Society of Bangladesh, Science 40 (1): 107-119. Kabir, T., M. Salehin, and G. Kibria. 2015. Delineation of physical factors of cyclone aila and their implications for different vulnerable groups. Proceedings of the 5th International Conference on Water \& Flood Management (ICWFM-2015), organized by IWFM, BUET, Dhaka.

Karim, Z., S.G. Hussain, and M. Ahmed. 1990. Salinity problems and crop intensification in the coastal regions of Bangladesh. Soils publication no. 33. Dhaka: Bangladesh Agricultural Research Council (BARC).

Lázár, A.N., D. Clarke, H. Adams, A.R. Akanda, S. Szabo, R.J. Nicholls, Z. Matthews, D. Begum, A.F.M. Saleh, M.A. Abedin, A. Payo, P.K. Streatfield, C. Hutton, M.S. Mondal, and A.Z.M. Moslehuddin. 2015. Agricultural livelihoods in coastal Bangladesh under climate and environmental change A model framework. Environmental Science-Processes and Impacts 17 (6): 1018-1031. https://doi.org/10.1039/c4em00600c.

Mondal, M.K., T.P. Tuong, S.P. Ritu, M.H.K. Choudhury, A.M. Chasi, P.K. Majumder, M.M. Islam, and S.K. Adhikary. 2006. Coastal water resource use for higher productivity: Participatory research for increasing cropping intensity in Bangladesh. In Environment and livelihoods in tropical coastal zones: Managing agriculture-fishery-aquaculture conflicts, ed. C.T. Hoanh, T.P. Tuong, J.W. Gowing, and B. Hardy. Wallingford: CAB International.

Murshid, S.M. 2012. Impact of sea level rise on agriculture using groundwater in Bangladesh. MSc thesis CoMEM programme, University of Southampton. https://repository.tudelft.nl/islandora/object/uuid:e484b9b8-e1d1-40b199ee-5c7a274ef500/?collection=research. Accessed 22 May 2017. 
Rahman, M.M., V.R. Giedraitis, L.S. Lieberman, T. Akhtar, and V. Taminskiene. 2013. Shrimp cultivation with water salinity in Bangladesh: The implications of an ecological model. Universal Journal of Public Health 1 (3): 131-142. http://dx.doi.org/10.13189/ujph.2013.010313.

Rasel, H.M., M.R. Hasan, B. Ahmed, and M.S.U. Miah. 2013. Investigation of soil and water salinity, its effect on crop production and adaptation strategy. International Journal of Water Resources and Environmental Engineering 5 (8): 475-481. https://doi.org/10.5897/IJWREE2013.0400.

Rashid, M., and M.S. Islam. 2007. Adaptation to climate change for sustainable development of Bangladesh agriculture. Bangladesh country paper for the 3rd session of the Technical Committee of Asian and Pacific Center for Agricultural Engineering and Machinery (APCAEM), November 20-21, Beijing.

Salehin, M., M.S. Mondal, D. Clarke, A. Lazar, M. Chowdhury, and S. Nowreen. 2014. Spatial variation in soil salinity in relation to hydro-climatic factors in southwest coastal Bangladesh. Deltas in Times of Climate Change II, September 24-26, Rotterdam.

SRDI. 2010. Saline soils of Bangladesh. Dhaka: Soil Resources Development Institute (SRDI), Ministry of Agriculture, Government of the People's Republic of Bangladesh.

Open Access This chapter is licensed under the terms of the Creative Commons Attribution 4.0 International License (http://creativecommons.org/licenses/ by/4.0/), which permits use, sharing, adaptation, distribution and reproduction in any medium or format, as long as you give appropriate credit to the original author(s) and the source, provide a link to the Creative Commons license and indicate if changes were made.

The images or other third party material in this chapter are included in the chapter's Creative Commons license, unless indicated otherwise in a credit line to the material. If material is not included in the chapter's Creative Commons license and your intended use is not permitted by statutory regulation or exceeds the permitted use, you will need to obtain permission directly from the copyright holder.

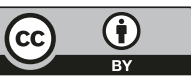

